\title{
Does ageing aggravate Parkinsonian disability?
}

\author{
J Blin, B Dubois, A $M$ Bonnet, $M$ Vidailhet, $M$ Brandabur, Y Agid
}

\begin{abstract}
The influence of age of onset of Parkinson's disease on the severity and the pattern of motor symptoms was investigated by comparing the motor scores with and without levodopa therapy in two groups of patients divided according to age of onset (early $<50$, late $>60$ years) and matched for disease duration ( $n=69$ in each group, Study I). The baseline score, that is, the motor disability of patients when off levodopa, was similar in the early- and late- onset groups. In contrast, the residual motor score, assessed when the effect of levodopa treatment was maximum and stable, was significantly higher in the late onset group. When the two groups of patients were matched, in addition, for their residual motor score $(n=54$ in each group, Study II), no difference was observed between the early and late onset groups, except for gait disorder which was more severe in older patients. These results suggest that age of onset mainly affects the response to levodopa therapy, because it may increase the prevalence of non-dopaminergic lesions of the brain, including those responsible for gait disorders.
\end{abstract}

There is some evidence that age of onset of Parkinson's disease (PD) influences the course of the disease. The progression of the disability is more rapid in patients with an older age of onset, ${ }^{12}$ who have a greater risk of intellectual decline, ${ }^{3-5}$ and a reduced response to levodopa treatment. ${ }^{6}$ This age-related increase in the severity of the disability may result from more severe degeneration of the nigrostriatal dopaminergic pathway in late onset patients, but it may also be the consequence of more diffuse brain lesions involving non-dopaminergic neuronal systems. In the latter case, it may be asked whether these additional neuronal lesions are part of the pathological process characteristic of PD or whether they result from a superimposed agerelated phenomenon. To answer these questions, we evaluated the severity and the pattern of Parkinsonism in a large group of PD patients according to their age at onset of the disease, with a special reference to the response of motor symptoms to levodopa treatment.

\section{Material and methods}

A group of 321 patients with Parkinson's disease, mean (SEM), age $63.5(0.6)$ years; duration of disease $7.9(0.3)$ years, were studied retrospectively. Patients were admitted to hospital for evaluation of motor status and response to levodopa treatment to adjust anti-Parkinsonian therapy. All patients included in this study fulfilled the following criteria:

1) Diagnosis of PD established on the basis of the existence of either akineto-rigid syndrome and/or resting tremor, with a good response to levodopa treatment which remained greater than $10 \%$ over time (greater than $25 \%$ in 269 cases);

2) Exclusion of Parkinsonian syndrome resulting from Von Economo encephalitis, chronic administration of neuroleptic drugs and degenerative disorders such as progressive supranuclear palsy and multiple system atrophy. Evaluation of motor performance was assessed with a modified Columbia rating scale ranging from 0 to 92 (global score), ${ }^{7}$ divided into 23 motor subscores with a $0-4$ rating each: the akinesia score was composed of eight different items and varied from 0 to 32; tremor and rigidity were each scored from 0 to 20 ( 5 subscores); speech disorder, gait disorder and postural instability were rated 0 to 4 (1 subscore). For each patient, motor disability was estimated:

3) When off medication, allowing us to measure the baseline motor score (the period of withdrawal of levodopa varied from 18 hours in patients with severe on-off phenomena until six days in the least affected ones);

4) During the "on" state, after levodopa therapy was reintroduced, at the time of the maximal effect of a single supraliminal morning dose, established for each individual as $50 \mathrm{mg}$ higher than the usual morning dose. The "residual motor score", evaluated when patients were "on", was considered to reflect symptoms unalleviated by levodopa. ${ }^{8}$

The influence of age of onset on Parkinsonism was first assessed on the whole group of 321 patients. To study the role of ageing on the pattern of motor disability, the individual motor subscores were compared in two groups of patients ( $n=69$ in each group) according to age of onset of the disease (early onset group: <50 years; late onset group: $>60$ years) and matched for the duration of the disease (study 1). The same patients were then matched for the residual motor score under 


\begin{tabular}{|c|c|c|c|c|c|}
\hline & $n$ & $\begin{array}{l}\text { Age } \\
\text { (years) }\end{array}$ & $\begin{array}{l}\text { Duration } \\
\text { of disease } \\
\text { (years) }\end{array}$ & $\begin{array}{l}\text { Duration of } \\
\text { levodopa } \\
\text { treatment } \\
\text { (years) }\end{array}$ & $\begin{array}{l}\text { Levodopa } \\
\text { daily dose } \\
\text { (mg) }\end{array}$ \\
\hline $\begin{array}{l}\text { Study } 1 \\
\text { Young onset ( } \leq 50 \text { years) } \\
\text { Late onset ( } \geq 60 \text { years) }\end{array}$ & $\begin{array}{l}69 \\
69\end{array}$ & $\begin{array}{l}51 \cdot 6(0.8) \\
73.5(0.6)^{\star}\end{array}$ & $\begin{array}{l}7 \cdot 7(0.5) \\
7 \cdot 7(0.5)\end{array}$ & $\begin{array}{l}6.4(0.5) \\
6.6(0.6)\end{array}$ & $\begin{array}{l}669(46) \\
730(44)\end{array}$ \\
\hline $\begin{array}{l}\text { Study } 2 \\
\text { Young onset ( } \leq 50 \text { years) } \\
\text { Late onset ( } \geq 60 \text { years) }\end{array}$ & $\begin{array}{l}54 \\
54\end{array}$ & $\begin{array}{l}52 \cdot 2(0 \cdot 8) \\
73 \cdot 7(0 \cdot 7)^{\star}\end{array}$ & $\begin{array}{l}7.8(0.5) \\
8 \cdot 1(0.6)\end{array}$ & $\begin{array}{l}6 \cdot 4(0.5) \\
7 \cdot 1(0.7)\end{array}$ & $\begin{array}{l}687(52) \\
722(51)\end{array}$ \\
\hline
\end{tabular}

Results are expressed as mean (SEM)

$\star: p<0.001$ when compared to young onset group

levodopa treatment ( $\mathrm{n}=54$ in each group, study 2). The characteristics of the patients are listed in table 1.

Correlations were performed using Pearson's linear regression, and mean comparisons were made with Student's paired $t$ test.

\section{Results}

EFFECT OF AGE AT ONSET OF THE DISEASE ON THE RESPONSE OF MOTOR DISABILITY TO LEVODOPA TREATMENT IN PATIENTS WITH PARKINSON'S DISEASE

Age at onset of the disease was negatively correlated with the response of patients to levodopa therapy, defined as the percentage improvement of motor scores between the "on" and "off" states ( $\mathrm{n}=321 ; \mathrm{r}=0.27$; $\mathrm{p}<0.001$ ), although there was marked variability among patients (fig 1). A similar result was obtained when the response of patients to levodopa treatment was assessed by estimation of the levodopa responsive motor score, that is, the difference between the baseline and the residual motor score under levodopa treatment (results not shown).

EFFECT OF AGE AT ONSET OF THE DISEASE ON MOTOR DISABILITY IN PARKINSONIAN PATIENTS WITH A SIMILAR DURATION OF THE DISEASE (STUDY 1).

No differences were observed between the baseline motor scores of the early and late onset groups, either for the global score or the individual subscores for akinesia, rigidity, tremor, speech disorder, postural instability and gait disorder (table 2). In contrast, the global residual motor score as well as the individual residual subscores for akinesia, tremor, rigidity, postural instability and gait disorder were significantly higher in the late onset group compared with the early onset group.

INFLUENCE OF AGE AT ONSET OF THE DISEASE ON MOTOR DISABILITY IN PARKINSONIAN PATIENTS ADDITIONALLY MATCHED FOR THEIR RESIDUAL MOTOR SCORES UNDER LEVODOPA TREATMENT (STUDY 2).

When the young- and late-onset groups of study 1 were matched in addition for their residual motor scores, the global residual score and the various subscores were similar in the young- and late-onset groups, except for gait disorder which was more severe in older patients (table 3 ).

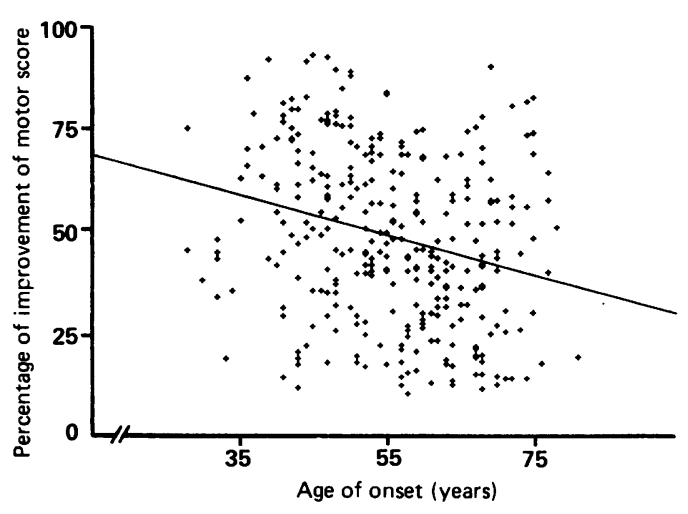

Figure 1 Age of onset and response to levodopa treatment in patients with Parkinson's disease $(n=321 ; r=0.27$; $p<0.001)$.

\section{Discussion}

The design of the study made it possible to investigate specifically the effect of age of onset of the disease on the motor pattern of Parkinsonism. Although the patients were matched only for duration of the disease, no differences were observed for the global baseline motor score (that is, the motor score evaluated in the off state) or for any of the individual motor subscores between the young and late onset groups (table 2). This suggests that Parkinsonism was similar in the two groups. Possible variations in the baseline state cannot be excluded but should not interfere markedly with motor scoring since disability was evaluated only when the Parkinsonian symptoms were the most severe and stable over time.

Age at onset of the disease mainly affected the response to levodopa therapy as indicated by:

1) The negative correlation between age of onset of the disease and the percentage improvement induced by levodopa (fig 1), although several patients with a late age at onset improved to the same extent as younger patients;

2) The higher residual motor score under levodopa therapy in the late onset group (table 2). It may be argued that the residual motor score (assessed when the effect of levodopa was maximum) depended on the dose used. However, the single dose of levodopa administered before motor scoring was supraliminar (see methods). These results suggest that young- and late- onset patients are disabled to the same extent after similar periods of evolution of the disease but older patients have symptoms less responsive to levodopa therapy. 
Table 2 Motor scores of young-onset and late-onset PD patients matched for duration of the disease

\begin{tabular}{|c|c|c|c|c|c|c|c|c|}
\hline & $\begin{array}{l}\text { Age at } \\
\text { onset }\end{array}$ & $\begin{array}{l}\text { Global } \\
\text { score }\end{array}$ & Akinesia & Tremor & Rigidity & $\begin{array}{l}\text { Speech } \\
\text { disorder }\end{array}$ & $\begin{array}{l}\text { Postural } \\
\text { instability }\end{array}$ & $\begin{array}{l}\text { Gait } \\
\text { disorder }\end{array}$ \\
\hline $\begin{array}{l}\text { Baseline motor score } \\
\text { Young onset ( } \leq 50 \text { years) } \\
\text { Late onset ( } \geq 60 \text { years })\end{array}$ & $\begin{array}{l}43.9(0 \cdot 6) \\
65 \cdot 8(0 \cdot 6)\end{array}$ & $\begin{array}{l}32.9(1.9) \\
31.7(1.5)\end{array}$ & $\begin{array}{l}16.4(0.9) \\
15.9(0.8)\end{array}$ & $\begin{array}{l}3.3(0.4) \\
2.9(0.4)\end{array}$ & $\begin{array}{l}7 \cdot 1(0 \cdot 5) \\
6 \cdot 2(0 \cdot 4)\end{array}$ & $\begin{array}{l}1.4(0.1) \\
1.5(0.1)\end{array}$ & $\begin{array}{l}1.3(0 \cdot 2) \\
1.6(0.1)\end{array}$ & $\begin{array}{l}1 \cdot 8(0 \cdot 1) \\
2 \cdot 1(0 \cdot 1)\end{array}$ \\
\hline $\begin{array}{l}\text { Residual motor score } \\
\text { Young onset ( } \leq 50 \text { years) } \\
\text { Late onset ( } \geq 60 \text { years })\end{array}$ & & $\begin{array}{l}12.9(1.0) \\
19 \cdot 6(1.3)^{\star \star \star}\end{array}$ & $\begin{array}{l}6.7(0.6) \\
9.8(0.8)^{\star \star}\end{array}$ & $\begin{array}{l}0.4(0.2) \\
1.0(0.2)^{\star}\end{array}$ & $\begin{array}{l}2.7(0.3) \\
3.7(0.4)^{\star}\end{array}$ & $\begin{array}{l}0.9(0 \cdot 1) \\
1 \cdot 1(0 \cdot 1)\end{array}$ & $\begin{array}{l}0.7(0 \cdot 1) \\
1.3(0 \cdot 1)^{\star \star}\end{array}$ & $\begin{array}{l}0.8(0 \cdot 1) \\
1.6(0 \cdot 1)^{\star \star \star}\end{array}$ \\
\hline
\end{tabular}

Results are expressed as mean (SEM)

$\star: \mathrm{p}<0.05 ;_{\star \star}: \mathrm{p}<0.01 ;_{\star \star \star}: \mathrm{p}<0.001$

Table 3 Residual motor scores of young-onset and late-onset patients with Parkinson's disease additionally matched for their global residual motor score

\begin{tabular}{|c|c|c|c|c|c|c|c|c|}
\hline & $\begin{array}{l}\text { Age at onset } \\
\text { of disease }\end{array}$ & $\begin{array}{l}\text { Global } \\
\text { score }\end{array}$ & Akinesia & Tremor & Rigidity & $\begin{array}{l}\text { Speech } \\
\text { disorder }\end{array}$ & $\begin{array}{l}\text { Postural } \\
\text { instability }\end{array}$ & $\begin{array}{l}\text { Gait } \\
\text { disorder }\end{array}$ \\
\hline $\begin{array}{l}\text { Young onset ( } \leq 50 \text { years) } \\
\text { Late onset ( } \geq 60 \text { years) }\end{array}$ & $\begin{array}{l}44.5(0 \cdot 6) \\
65 \cdot 5(0 \cdot 7)\end{array}$ & $\begin{array}{l}15 \cdot 2(1 \cdot 1) \\
15 \cdot 1(1 \cdot 0)\end{array}$ & $\begin{array}{l}8.0(0.7) \\
7 \cdot 4(0.6)\end{array}$ & $\begin{array}{l}3 \cdot 2(0 \cdot 4) \\
2 \cdot 7(0 \cdot 3)\end{array}$ & $\begin{array}{l}0.4(0.2) \\
0.8(0.2)\end{array}$ & $\begin{array}{l}1.0(0 \cdot 1) \\
0.9(0 \cdot 1)\end{array}$ & $\begin{array}{l}0.8(0 \cdot 1) \\
1.0(0 \cdot 1)\end{array}$ & $\begin{array}{l}0.9(0 \cdot 1) \\
1 \cdot 4(0 \cdot 1)^{\star \star \star}\end{array}$ \\
\hline
\end{tabular}

Results are expressed as mean (SEM)

$\star \star \star: \mathrm{p}<0.001$

What is the underlying pathophysiological significance of these results? It has been proposed that the residual motor score, which is the part of the motor score not alleviated by levodopa treatment, reflects non-dopaminergic lesions in the brain..$^{910}$ In the same way, the levodopa responsive score, which is the part of the motor score alleviated after administration of a supraliminar dose of levodopa (the difference between baseline and residual score), is an index of levodopa-sensitive symptoms thought to reflect the lesion of dopaminergic neurons. The fact that the residual motor score was higher and that the amplitude of the response to levodopa treatment was smaller in patients with late onset of the disease is compatible with the assumption that ageing increases the severity of non-dopaminergic lesions of the brain in PD patients. Accordingly, two forms of the disease may be distinguished: a young-onset form, characterised by severe and selective degeneration of dopaminergic neuronal systems (that we suggest should be called a "pure or predominant dopaminergic" form of the disease), and a late-onset form with additional non-dopaminergic lesions that may account for the decreased response to levodopa treatment in this group. Such a clearcut distinction cannot be generalised, however, since several patients with late-onset of the disease responded well to levodopa treatment and vice versa (fig 1 ).

What part of the motor symptomatology is supported by the putative additional non dopaminergic lesions seen in older PD patients? The fact that almost all the individual residual subscores (akinesia, tremor, rigidity, postural instability and gait disorder) were more severe in late-onset compared with early onset PD patients suggests that the effect of levodopa on Parkinsonian motor disability is decreased as a reflect of additional brain neuronal lesions although other explanations can be proposed. The re-establishment of a normal striatal dopaminergic transmission by levodopa, that explains the beneficial effect of the drug in patients, may be attenuated by lesions situated either outside of or downstream from the nigrostriatal dopaminergic pathway. ${ }^{10}$ Moreover, when the early-and lateonset groups of patients were matched for their global residual score (assessed when clinical benefit was maximal) gait disorder remained significantly more severe in the late onset group suggesting that this symptom may be the most dependent on non-dopaminergic lesions. This conclusion is in agreement with the weak response of gait disorders to levodopa therapy that has been repeatedly demonstrated in PD. ${ }^{29}$

1 Gerstenbrand F, Ransmayr G. Nosography of Parkinson's disease. J Neural Trans 1986;22(suppl):119-28.

2 Diamond SG, Markham CH, Hoehn MM, McDowell FH Muenter MD. Effect of age at onset on progression and mortality in Parkinson's disease. Neurology 1989;39: mortality

3 Lieberman AN, Dziatolowski M, Kupersmith $\mathrm{M}$, et al. Dementia in Parkinson's disease. Ann Neurol 1979;6: 355-9.

4 Hietanen $M$, Teräväinen $H$. The effect of age of disease onse on neuropsychological performance in Parkinson's disease. J Neurol Neurosurg Psychiatry 1988;51:244-9.

5 Dubois B, Pillon B, Sternic N, Lhermitte F, Agid Y. Ageinduced cognitive disturbances in Parkinson's disease. Neurology 1990;40:38-41.

6 Cedarbaum JM, McDowell FH. Sixteen-year follow-up of 100 patients begun on Levodopa, in 1968: Emerging problems. Adv Neurol 1986;45:469-72.

7 Lhermitte F, Agid Y, Signoret JL. Onset and end-of-dose levodopa induced dyskinesias. Arch Neurol 1978;35: 261-3.

8 Esteguy M, Bonnet AM, Kefalos J, Lhermitte F, Agid Y. Le test à la L-Dopa dans la maladie de Parkinson. Rev Neurol test à la L-Dopa dans la mar

9 Bonnet AM, Loria Y, Saint-Hilaire MH, Lhermitte F, Agid $Y$. Does long-term aggravation of Parkinson's disease result from non dopaminergic lesions? Neurology 1987 37:1539-42.

10 Agid Y, Graybiel AM, Ruberg M, et al. The efficacy of levodopa treatment declines in the course of Parkinson's disease: do non dopaminergic lesions play a role? Parkinson's disease: anatomy, pathology and therapy. In Streifler MB, Korczin AD, Melamed E, Youdim MBH, eds. Advances in neurology, Vol 53. New York: RavenPress, 1990 